\title{
Substance-P Receptor
}

National Cancer Institute

\section{Source}

National Cancer Institute. Substance-P Receptor. NCI Thesaurus. Code C41023.

Substance-P receptor (407 aa, $\sim 46 \mathrm{kDa}$ ) is encoded by the human TACR1 gene. This protein is involved in tachykinin-dependent G protein-coupled receptor signaling. 